\title{
Foodstuffs in Siberia and the World Market: Production and Export of Ecologically Clean Products
}

\author{
Vasiliy Kuimov \\ Yulija Suslova \\ Eva Shcherbenko \\ Siberian Federal University, 79 Svobodny, Krasnoyarsk, 660041, Russia \\ E-mail:kuimov1945@mail.ru
}

\section{Doi:10.5901/mjss.2015.v6n5s4p212}

\begin{abstract}
The article analyzes the issues of development of the food market by certain products and territories against the background of the population growth. Special focus is made on the analysis of the food production capacity in the territories of Siberia and the Far East that are capable of producing ecologically clean products and their export to heavily populated developing countries
\end{abstract}

Keywords: Siberia, food, market, production, export

\section{Introduction}

The world and Siberian food markets, as the review of their research shows, are developing dynamically. The most important breakthrough for providing the food security of many countries in the $20^{\text {th }}$ century were the "green revolutions" in agriculture and the new technologies in animal breeding (Zerkalov, 2009). Countries such as India, China, Indonesia, Pakistan, and many others have provided themselves with main part of traditional food (grains, dairy products, vegetables, fruit, fish, and they have begun to consume more meat and eggs). Further development based on modern technologies can significantly increase the productivity of livestock and plant breeding, as well as the farming culture. An important factor was the rapid development of the food market in a number of countries - Australia, New Zealand, South America - and the advanced development of the food market in the developed countries - the USA, Canada, Germany, France, the UK, and others.

As the analysis shows, the growth in food production in the world is parallel to the increase in population. However, about 1 billion inhabitants of the planet have excessive consumption, while a significant part of the population of underdeveloped countries (about one third of the world's population) is unable to obtain a balanced diet, and either suffers or risks hunger (Global'nye tendentsii 2030, 2012).

According to the Food and Agriculture Organization (FAO), the growth of food production and reduction in the unit prices has remained in 2014. FAO forecast the crop of wheat, rice, and coarse grains in the amount of up to 2.5 billion tons. Herewith, they expected that wheat production would decline slightly to 707.2 million tons and maize crop-to 716.9 million tons in the United States (Agrarnye rynki).

Experts of the union of European grain traders COCERAL estimate the cereal harvest in the European Union in 2014 at 323 million tons or by 22 million tons more than the previous year's value. A significant increase was observed in wheat production-148.4 million tons in 2014 compared to 136.5 million tons in 2013 (8.7\%). The volume of grain corn increased from 63.2 to 73.5 million tons (16\%), while barley production remained at the level of 60 million tons. According to COCERAL's estimates, rapeseed production will continue to grow in the EU - by $16 \%$ to 24.1 million tons compared to 20.8 million tons in the previous year. Thus, the world production of wheat, corn, and oilseed products in 2014/2015 will be growing (Global'nye tendentsii 2030, 2012; Agrarnye rynki, 2015; RosInvest.Com).

\section{Method}

Similar processes are typical of the production of meat, milk, and their products. As of year-end 2012, beef production was observed in many countries and reached 57 million tons. A moderating decline was organized in the USA and the 
EU, and a rapid growth — in India, Brazil, Argentina (IKAR; FAO: Obzor mirovogo rynka miasa i miasnykh produktov).

Table 1. Beef production by countries from 2009 to 2013, thousand tons (IKAR; FAO: Obzor mirovogo rynka miasa i miasnykh produktov).

\begin{tabular}{|l|c|c|c|c|c|}
\hline Countries & 2009 & 2012 & 2013 & Growth rate & Increment rate, in \% \\
\hline The USA & 11,891 & 11,709 & 11,273 & -436 & -3.72 \\
\hline Brazil & 8,935 & 9,210 & 9,375 & +165 & +1.79 \\
\hline The EU & 7,913 & 7,815 & 7,700 & -115 & -1.47 \\
\hline China & 5,764 & 5,540 & 5,580 & +40 & +0.72 \\
\hline India & 2,514 & 3,643 & 4,168 & +525 & +14.41 \\
\hline Argentina & 2,380 & 2,620 & 2,780 & +160 & +6.11 \\
\hline Australia & 2,106 & 2,140 & 2,185 & +45 & +2.10 \\
\hline Mexico & 1,705 & 1,815 & 1,795 & -20 & +1.10 \\
\hline Pakistan & 1,441 & 1,400 & 1,400 & 0 & 0 \\
\hline Russia & 1,460 & 1,350 & 1,345 & -5 & -0.37 \\
\hline Total & 47,109 & 47,242 & 47,601 & +359 & +0.76 \\
\hline Totally with account of other countries & 57,167 & 57,170 & 57,525 & +355 & +0.62 \\
\hline
\end{tabular}

In Russia, a decrease is observed, and by the year-end 2014, the production of beef, as estimated by the Ministry of Agriculture of the Russian Federation, will make 1.6 million tons. Herewith, beef import as of year-end 2014 has reduced by $11.8 \%$.

The world milk market had saturated and demonstrated a steady growth to 784 million tons in 2013. Milk consumption is associated with traditions and family budgets. In different countries, consumption of milk varies considerably. In Russia, the share of milk and dairy products ranges from 14 to 17 percent.

Table 2. World dairy market (Sel'skoe khoziaistvo Rossii: itogi 2013 goda)

\begin{tabular}{|l|c|c|c|}
\hline & 2011 & 2012 & 2013 \\
\hline Total quantity of milk (in million tons) & 745.5 & 767.4 & 784.4 \\
\hline Total sales of milk (in million tons) & 49.7 & 53.7 & 54.7 \\
\hline Milk consumption per capita in the world (kg/person a year) & 105.7 & 107.6 & 108.7 \\
\hline Milk consumption per capita in developed countries (kg/person a year) & 235.3 & 237.9 & 238.0 \\
\hline
\end{tabular}

Compiled based on (RosInvest.com).

Consumption of milk in different countries is shown in Table 3.

Table 3. Consumption of milk and cheese in different countries (kg/1 person) (Sel'skoe khoziaistvo Rossii: itogi 2013 goda)

\begin{tabular}{|l|c|c|}
\hline Country & Liquid milk (kg per capita) & Cheese (kg per capita) \\
\hline China & 3 & 0.1 \\
\hline The UK & 110 & 10.5 \\
\hline Australia & 100 & 11 \\
\hline The USA & 85 & 15.5 \\
\hline The EU & 90 & 19 \\
\hline France & 100 & 25 \\
\hline Greece & 70 & 29 \\
\hline Finland & 175 & 16 \\
\hline
\end{tabular}

According to the Organization for Economic Cooperation and Development (OECD), the annual growth of the world food market provides with the necessary food the annual gain in the world population equal to 80-85 million people. Expansion of food production will take place in countries that have agricultural areas and the latest technology and that have available land for agriculture (Australia, New Zealand, Siberia, some parts of Africa, and others.). 


\section{Imports of Agricultural Products in Russia and the Domestic Production Capacity}

Most researchers distinguish the import of goods that are not produced in the country but are in demand (the import of such goods to Russia amounts to about 11 billion rubles), and goods that can be manufactured, but less than consumed. Russia imports apples and pears for more than USD 1 billion and vegetables for more than USD 2.5 billion. Problems of import are more complex, and it is necessary to take into account the demand of the population for their preferred products. Import in Russia continues to remain high, and in 2013, it amounted to about USD 42 billion (about $34 \%$ of all imported goods). According to preliminary estimates, 2014 has shown the same performance with a slight decline.

The situation did not change with the entry of Russia into the WTO. For the first year - 2013 - of work in the WTO, there was a reduction in the import of meat and its products by $12.4 \%$ (except poultry), and an increase in the import of milk powder by $48 \%$, and oil and other dairy fats supply by $16.1 \%$. The trend continued in 2014 until the sanctions were imposed (Kuimov, Suslova, Shcherbenko, and Pankova, 2015).

The largest segment of the food imports, including 2014, was meat (beef, pork), which were imported each year for USD 6 billion and even more, and fish and fishery products - for USD 2.5 billion.

The import of milk and dairy products remains significant (up to $30 \%$ of consumption). The main supplier is Belarus (47\% of the imported volume) (Kuimov, Suslova, Shcherbenko, and Pankova, 2015; Kuimov and Shcherbenko, 2015).

Businesses in many areas of Russia have become actively engaged in meat and milk production, and in 2013, the production of cattle meat amounted to 538 thousand tons, with the increment at 5 thousand tons compared to 2012 . The growth continued in 2014 (Kuimov and Shcherbenko, 2015).

According to the Ministry of Agriculture in 2014, the volume of marketable milk delivered for processing was about 20.5 million tons, which is almost by 1.5 million tons more than in 2013 (Rosinvest.com).

In Russia, in accordance with the "State Program of Agriculture Development and Regulation of Agricultural Products, Raw Materials, and Food for 2013-2020," the state support complies with the WTO requirements, and the state funding in 2014 amounted to 197.8 billion rubles, which is by $44 \%$ more than the funding in 2012, with the livestock breeding activities funded more fully. The main lines of the regional co-financing are aimed at the implementation of programs: the development of pig breeding - $62.6 \%$, poultry - 36.7\%, subsidies for investment and short-term loans$16 \%$, and for social development of rural areas - 37.7\% (Gosudarstvennaia programma razvitia sel'skogo khoziaistva, regulirovaniia rynkov sel'skokhoziaistvennoi produktsii, syr'ia i prodovol'stviia na 2013-2020 g.g).

The total agriculture funding in the consolidated budget of the Federation and regions amounted to 267.5 billion rubles, or $0.4 \%$ of Russia's GDP, in 2014. The agricultural budget of the EU equals to 129.9 billion euros, or $1.1 \%$ of the GDP of the EU. According to the OECD, the total support to agricultural producers, divided by the value of the agricultural production, in Russia in 2013 amounted to 13\%, in the EU-20\%, and in the US - 7\%. In general, the support for agricultural producers in Russia is comparable with their support in the US and the EU.

\section{Food Capacity of Siberia and the Far East-the Territories Adjacent to the World Centers of Population}

Siberia and the Far East can be attributed to the sparsely populated areas, and, therefore, their agricultural potential is not in full demand. Taking into account the geographic, climatic, huge territory conditions, we can see that there are large land resources here, including both cropland and pasture; unique soils; abundance of fresh water in the presence of large rivers; historically rooted culture of agriculture; capacity for the development of scientific research. As the main directions of agriculture development, the programs of the regions located in Siberia have determined:

production of food products for the regional market, which considerably reduces transportation at advanced processing;

interregional cooperation of markets, and provision with domestic food with forming large nationwide integrated structures;

access to the world market, especially in the Asia-Pacific countries, where there is a growth of the quality of life of the population and growing consumption.

The emerging countries in Asia, where a rapid economic growth is taking place, and where about $40 \%$ of the world population is concentrated, are becoming the leading consumer of food, including the ecologically clean one. As noted by a number of researchers (see the report "Development until 2030"), in these countries, along with the ultra-intense technologies, the quality of the soil significantly deteriorates, and there is a lack of fresh water for agriculture and livestock production.

Such processes are observed in China, where in recent years, there has been a decrease in wheat production caused by the intensive use of land (only $9 \%$ of the territory is used for agriculture), lowering of the ground water, and soil 
erosion. These problems are typical for India and other countries in the region, where the economic growth is accompanied by the effect of the "law of Bennett" - the consumption of meat in China for 20 years has increased from $19.6 \mathrm{~kg}$ in 1985 to more than $60 \mathrm{~kg}$ at present. The growth in food consumption in the region will continue (Zerkalov, 2009).

Against this background, the closely located territories of Siberia and the Far East are a promising resource. Here, there are necessary areas, but the resources - people, money, new technologies - are scarce. Already now, the intercompany cooperation in the production of food in the lands of Siberia and the Far East is manifested. Chinese citizens organize in Siberian farms production of vegetables, most of which are sold within Russia. An accurate assessment of the Russian land area leased to Asian companies is currently hardly possible. According to the official statistics, it is very small (no more than 600-700 thousand hectares across Russia), but the real values are many times more - much land that is actually leased by foreigners, is semi-legally registered to the names of Russian citizens.

Wild plants still are the most important source of development of ecological food production in Siberia. Wild plants include berries, mushrooms, edible herbs, nuts, and other ecologically clean natural products. According to experts, the cost of the annual crop of these products in Russia and Siberia exceeds 20 billion rubles, while actually processed and sold just about 150 thousand tons of wild plants for 3-4 billion rubles. The main obstacle to the development of the market of wild plants is the lack of organized international markets, attractive brands and knowledge of these products. Products from Siberia, as an ecologically clean, resource-rich area, and the wild plants in particular, can be a driver to promote products produced from agricultural and forestry raw materials growing on its territory.

There are sufficient resources to fulfill it. The forestry of the Krasnoyarsk Region alone is over 164.0 million hectares, which is more than $45 \%$ of the total forest area of Siberia. Forests cover more than $65 \%$ of the region's area and $85 \%$ of them are conifers. Food forest resources of the region include wild fruit, herbs, berries, nuts, mushrooms, seeds, birch sap, and similar forest resources. Reference: previously, more than 110 companies were engaged in harvesting wild plants in the Krasnoyarsk Region alone. According to the CSA, procurement of pine nuts in the RSFSR equaled to: in $1959-4,648 \mathrm{t}$, in $1960-10,231 \mathrm{t}$, in $1961-10,630 \mathrm{t}$, in $1962-2,978 \mathrm{t}$, in $1963-2,054 \mathrm{t}$, in $1964-$ $12,369.9$ t. The real capacity is many times higher. According to the Institute "Lesproekt," the average annual biological yield of nuts is no less than 1,727 thousand tons, and the capacity of collection equals to 424 thousand tons a year, which is 35 times the volume of procurement in the best year of 1964. The implemented small capacity projects show that modern technology allows deep processing of wild plants, providing long-term storage and production of high-quality ecologically clean products. (Kuimov, Suslova, Shcherbenko, and Pankova, 2015; Kuimov and Shcherbenko, 2015; Kuimov and Shcherbenko, 2015).

A significant reserve for the development of food production in Siberia and the Far East are the already mastered lands and pastures that have been poorly used during the last 15-20 years. Many areas have reduced the amount of arable land, livestock, and ultimately food production. For example, in the Krasnoyarsk Region, despite the growth in recent years, the production of basic foodstuffs according to Regional Statistic Committee has been below the previously achieved level (Kuimov, Suslova, Shcherbenko, and Pankova, 2015; Kuimov and Shcherbenko, 2015) (See Table 4).

Table 4. Food production in the Krasnoyarsk Region

\begin{tabular}{|l|c|c|}
\hline Production in thousand tons & 1995 & 2012 \\
\hline Food production, thousand tons, including & 800.2 & 497.3 \\
\hline Meat, including by-products of 1 category & 52.8 & 47.9 \\
\hline Milk production & 423.2 & 223.3 \\
\hline
\end{tabular}

At the same time, significant amount of food, which has previously been produced here in the region, is imported for the population's needs.

Calculations based on the import-export-consumption method show the volume of necessary production in the region (see Table 5). 
Table 5. The minimum required meat production in the Krasnoyarsk Region.

\begin{tabular}{|l|c|c|c|c|}
\hline \multirow{2}{*}{ Product name } & \multicolumn{2}{|c|}{ Imported in 2012 } & $\begin{array}{c}\text { Exported outside the } \\
\text { region }\end{array}$ & $\begin{array}{c}\text { Minimum need for additional production } \\
\text { in the region (tons) }\end{array}$ \\
\cline { 2 - 4 } & total: & $\begin{array}{c}\text { including imported } \\
\text { foodstuffs }\end{array}$ & 2,875 & 4,124 \\
\hline Beef (tons) & 6,999 & 5,063 & 2,848 & 11,444 \\
\hline Pork (tons) & 14,292 & 7,121 & 337 & 770 \\
\hline Horse meat (tons) & 1,107 & 1,066 & 16,018 & 15,258 \\
\hline Poultry meat (tons) & 31,276 & 8,163 & & \\
\hline
\end{tabular}

The earlier used land, the experience of the implementation of large-scale livestock projects have not yet been lost and can be quickly restored, which will allow increasing the production by $30-40 \%$ based on the new productive crops and breeds of livestock, and it will be in demand both domestically and abroad.

With the systemic growth of retail trade turnover (in 2013, it increased compared with 2012 by $2 \%$ - up to 456.6 billion rubles), more than half of sales (56.9\%) relates to non-food products, which in 2013 amounted to 260 billion rubles.

The retail trade turnover in the Krasnoyarsk Region remained stable in 2014, and the sales of food products increased.

Summary: Siberia and the Krasnoyarsk Region in particular have the potential for a rapid growth in production and export of foodstuffs, including to the Asia-Pacific countries. The most promising lines of development are:

promotion to world food markets of the naturally produced grains, meat, and dairy products;

wild plants, including berries, mushrooms, and plant products are the most promising at the first stage;

in order to enter the world markets, it is necessary to create appropriate structures, including joint ventures with companies from the Asia-Pacific countries;

it is desirable to form the image of the Siberian food products as the "green line" products, including in the domestic market.

\section{Selected Lines of the Food Production Development and Import Substitution in the Krasnoyarsk Region}

A qualitatively new stage of the region and its separate territories development, including overcoming the decline in GRP expected in 2015-2017, may be implemented based on the formation of reproduction and sale systems, which would provide for the integration of the resources of business, power, and the region, the cooperation development within the framework of the production-trade-sale systems (clusters) in the agribusiness and forest industry, which buy goods from local producers and supply them to regional retailers (including the major chains), as well as to Russian regions and for export (Kuimov and Shcherbenko, 2015, Pilipchuk, 2011).

To implement the present stage, an integrated regional development project is developed based on network (cluster) interaction. With this purpose: based on the existing long-term strategic plans of development, with account of the zoning and production existing in the region, as well as other project materials, in close cooperation with municipalities, the programs of integrated development of territories and groups of territories of the region are developed, which complement each other and are integrated with each other, thus ensuring the production and sale of high-quality goods and services. The implementation of a new stage of development of the region requires:

supporting the efforts of retailers aiming to form joint logistic centers and organize procurement;

providing the formation and real support to the mass cooperation of households and farms, in the area of meat, milk, vegetables, and wild plants production through the development of fodder production, engineering, veterinary, and agricultural services and their cooperation with the logistic centers;

using in the public and municipal procurement systems primarily the products made in the region, which would allow producers to have a permanent demand and conditions for development;

Integration centers in these projects should be the purchase and distribution logistics centers (e.g. of the 4PLtype), which form a coherent assortment and promotion of regional brands (such as "Eniseyprodukt"), small business resources' cooperation with retailers and infrastructure, with which these products will be delivered to the retailers of the district, the neighboring cities, Krasnoyarsk, the neighboring regions, and be exported.

Such an integrated approach will allow the logistic centers to purchase products manufactured in the territories, provide advanced preparation of the goods for supply to retail chains and individual stores in the region. Modern retail chains and large stores will become the integrators in the system of development of products in demand. All this will contribute to the development of small and medium-sized enterprises, which will be integrated in the production and 
processing, trade and supply chains - the clusters - that will ensure the systematic development of food markets in the region, Siberia, Russia, and the exports to the Asia-Pacific countries.

The analysis performed shows that Siberia and the Far East of Russia have a significant potential for the production of food and its exports to the Asia-Pacific countries. The basis for this development may be the formation of a food cluster, particularly producing ecologically clean products and wild plants.

There is an appropriate capacity to achieve this target; especially there are fertile lands ready for agricultural use.

Table 6. The cultivated area in the region in all categories of farms (thousand hectares) (Current archives of the Agricultural Union of the Krasnoyarsk Region)

\begin{tabular}{|l|c|c|c|}
\hline Description & 1990 & 2010 & 2013 \\
\hline Total sown area & 2,879 & 1,461 & 1,517 \\
\hline Grains and legumes & 1,652 & 985 & 1,034 \\
\hline Vegetables & 8.2 & 8.9 & 8.9 \\
\hline
\end{tabular}

Table 6 shows that at the beginning of the active reforms in Russia (1991-1995), the acreage in the region was equal to 2,879 thousand hectares, including 1,652 thousand hectares sown with grain and leguminous crops. Here, 2.67 million tons of grain and leguminous crops in clean weight were produced, which was almost $900 \mathrm{~kg}$ per person living in the region. Currently, 1,362 thousand hectares of arable land, or $47.3 \%$ of total, are not used. There are also equally large opportunities for the growth in meat and milk production.

Table 7. Production of major livestock products in the Krasnoyarsk Region (Current archives of the Agricultural Union of the Krasnoyarsk Region)

\begin{tabular}{|l|c|c|}
\hline Description & 1990 & 2013 \\
\hline Milk production, thousand tons & 1,251 & 708 \\
\hline Cattle meat, thousand tons & 106 & 39.9 \\
\hline Pork, thousand tons & 72 & 70.4 \\
\hline Poultry meat, thousand tons & 28 & 35.8 \\
\hline Eggs production, million pieces & 1,008 & 838 \\
\hline
\end{tabular}

Total milk production has grown twice less from 1990 to 2013 - from 1,251 thousand tons to 708 thousand tons, though the yield has increased from $2,870 \mathrm{~kg}$ to $4,314 \mathrm{~kg}$ per cow. The beef production has significantly reduced from 106.0 to 39.9 thousand tons.

According to our estimates, the reclamation of the use of arable and farmland with account of the new varieties of crops and livestock productivity in the Krasnoyarsk Region alone will provide for the increment in the grain production by 30-35\% and livestock production — by 30-40\%. Similar reserves exist in all regions of Siberia and the Far East.

Siberia and its regions remain the large reserve of food production for the Asia-Pacific countries, where almost $40 \%$ of the world's population resides. By 2030, we expect a rapid rise in the living standards, which means a good demand for ecologically clean products (Global'nye tendentsii 2030, 2012). All this creates an opportunity to develop the production and export of food from Siberia.

\section{References}

Agrarnye rynki [Agricultural markets]. Retrieved from http://uga-port.org.ua/agrarnye-rynki [in Russian].

Current archives of the Agricultural Union of the Krasnoyarsk Region [in Russian].

FAO: Obzor mirovogo rynka miasa i miasnykh produktov [FAO: Review of the world market of meat and meat products]. Retrieved from http://meatinfo.ru/news/fao-obzor-mirovogo-rinka-myasa-i-myasnih-produktov-303676 [in Russian].

FAO: obzor mirovogo rynka moloka i molochnyh produktov [FAO: Review of the world market of milk and dairy products]. Retrieved from http://milknet.ru/nevs/fao-obzor-mirovogo-rinka [in Russian].

Global'nye tendentsii 2030: al'ternativnye miry. Publikatsii natsional'nogo Soveta po razvedke [Global Trends 2030: alternative worlds. Publications of the National Intelligence Council]. December 2012. Retrieved from http://eurasian-defence.ru/sites/default/files/DS /Documents /global-trends-2030-rus.pdf [in Russian].

Gosudarstvennaia programma razvitiia sel'skogo khoziaistva, regulirovaniia rynkov sel'skokhoziaistvennoi produktsii, syria $i$ prodovol'stviia na 2013-2020 g.g [The state program of agricultural development, regulation of agricultural products, raw 
materials and food for 2013-2020]. Retrieved from http://www.mcx.ru/navigation/docfeeder/show/342.htm [in Russian].

IKAR - The Institute for Agricultural Market Studies. Retrieved from http://ikar.ru/eng/.

Kuimov, V.V., \& Shcherbenko, E.V. (2015). [The food market of Siberia: whether it is possible to export to the Asia-Pacific region]. Zhurnal Sibirskogo federal'nogo universiteta, seriia: Gumanitarnye nauki - Journal of Siberian Federal University, Series: Humanitarian Sciances, 8, Supplement C, 166-179 [in Russian].

Kuimov, V.V., Suslova, lu.lu., Shcherbenko, E.V., \& Pankova, L.V. (2015). Marketingovye tekhnologii v razvitii rynkov prodovol'stvennykh tovarov regionov Sibiri: monografiia [Marketing technologies in the development of food markets of Siberia: monograph] (pp. 268). Krasnoyarsk: Siberian Federal University [in Russian].

Mirovoi rynok moloka. Analiz i prognoz rynkov [World market of milk. The market analysis and forecast] (2008). Retrieved from htth: I/www.ark-inform.com [in Russian].

Pilipchuk, A.V. (2011). Organizatsiia firmennykh torgovo-sbytovykh sistem v agropromyshlennom komplekse Belarusi [Organization of branded trade and marketing systems in the agribusiness of Belarus]. Gusakova, V.G., Ed. Minsk: Institute of System Research in Agroindustrial Complex of NAS of Belarus [in Russian].

RosInvest.com. Retrieved from rosinvest.com/acolumn/blog/mirovoi_prodovolstvenii_rinok/542.html [in Russian].

Roslnvest.com. Retrieved from rosinvest.com/acolumn/blog/mirovoi_prodovolstvenii_rinok/542.html [in Russian].

Sel'skoe khoziaistvo Rossii: itogi 2013 goda [Agriculture of Russia: Summary of 2013]. Retrieved from http://www.webeconomy.ru/index. php?page=cat\&cat=mcat\&mccat-192\&type=news\&newsid=2390 [in Russian].

Zerkalov, D.V. (2009). Prodovol'stvennaia bezopasnost'. Monografiia [Food safety. Monograph] (pp. 449). Kiyv: Basis [in Russian]. 